\title{
運転中における誘導電動機の可変周波電源 への再投入による過渡トルク特性
}

\begin{tabular}{|lr|}
\hline 論 文 \\
\hline $55-$ B 25 \\
\hline
\end{tabular}

$\begin{array}{llllll}\text { 正員 } & \text { 三 } & \text { 木 } & \text { 一 } & \text { 郎 } & \text { (明治大) } \\ \text { 正 員 } & \text { 松 } & \text { 瀬 } & \text { 貢 } & \text { 規 } & \text { (明治大) } \\ \text { 正 員 } & \text { 西 山 } & \text { 栄 } & \text { 枝 } & \text { (明治大) }\end{array}$

\section{1. まえがき}

誘導電動機は可变周波電源が容易に得られるように なったととおよで保守の容易さなどから周波数制御 による電動機システムの一部を構成し，その制御対象 として各方面で実用に供されている。とのような勛さ に伴って，可変周波電源で駆動される電動機の特性等

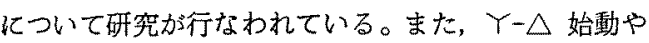
自動し。断器の安全性の問題に関連し, 商用掌源再投

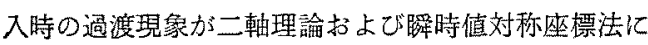
よって解析されている(1)ー(3)。最近, 一部の誘導電動機 に対して，可変周波電源により低周波始動を行ない， 所定の速度に達した後, 商用電源に切換える運転方法 が行なわれようとしている。とのようなことから，運 転中の誘導電動機を電源加ら開放し，短時間後，電生 上周波数の比を一定にした状態における可変周波電源 亿再投入した場合の訜導電動機の過渡現象(4)を明らか にすることは重要であると考えられる。

本論文に扎いては，まず，電源再投入時における誘 導電動機の過渡電流および過渡トルク式を瞬時值対称 座標法 ${ }^{(3)(5)} に よ り$ 導出した。次に，このトルク式上運 動方程式を組合せ，慣性負荷上しての直流発電㙨它連 結した状態に晾ける過渡トルクを電算機により求め た。とのようにして得られた結果，および二軸理論に よるシミュレーション結果を実測徂と比較し, 本解析 結果の要当性を確認した。再投入時の残留電瓜，再投 入電死およびそれらの位相関係などの条件は一般隹不 定であり，種々の場合がある。そこで，次に多くの数 值計算およひ夷測結果から過渡トルク特性に顕著な影 響を及はすす条件における代表的な例を示し，次の事柄

Characteristics of Transient Torque in Induction Motor due to Rapid Reconnection to Variable Frequency Supply. By Ichiro Miki, Member, Kouki Matsuse, Member \& Sakae Nishiyama, Member (Faculty of Engineering, Meiji University). 三木一郎：正員，明治大学工学部電気工学科

松唃貢規：正員，明浩大学工学部電気工学科

西山栄枝: 正具, 明治大学工学部霞気工学科

昭 $55-4$
について検討した。まず，電源再投入時に和ける過渡 トルク波形および負荷を含む慣性モ一メントの影響に ついて达へた後，再投入雷王位相と電源の周波数が過 渡トルク特性に及ぼす影響について調べた。そして最 娞に，残留電生上過渡最大卜ルクの関係について明ら 加した。なお，本研究では，一般用電勒機として広 く使用されている低压三相普通かで形誘導電䳠機を対 象にしている。

\section{2. 瞬時値対称座標法による過渡特性の解析}

\section{〈2・1〉解析における基本的な仮定および条件}

誘導電動機の可変周波電源への再投入時における過 渡特性の解析にあたり，誘盖電動機に関する基本的な 仮定は次のとおりである。

（1）淃線は固定子，回転子共平衡しており，正弦 波起磁力を発生する。

（2）飽和の影響は小さく，乙れを無視できる。

（3）うず電流㧍よびヒスデリシスけ㹕視でき，罕 げきは一様とする。

（4）電動機の抵抗およびインダクタンスは周波数 に関係なく一定である。

投入電源の条件については，

（5）電圧は变動せず，三相平衡な正弦波である。

(6) 線間電王 $V$ c周波数 $f$ は， $V / f \simeq$ 一定之 いう関係を保ち，本研究では定格が $200 \mathrm{~V}, 50 \mathrm{~Hz}$ の

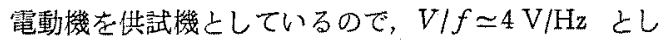
ている。

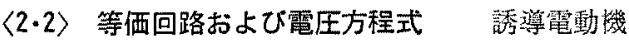
○瞬時值正相分等価回路を第 1 図に示す (3)。

電生方程式は，電源を再投入した時到を基準とする と，第 1 図より

$$
\begin{aligned}
& v_{s 1}=\left(R_{s}+P L_{s}\right) i_{s 1}+P L_{m} i_{r 1} \\
& O=\left(R_{r}+P L_{r}\right) i_{r 1}+P L_{m} i_{s 1}-e_{v 1} \\
& e_{v 1}=j \omega_{m}\left(L_{r} i_{r 1}+L_{m} i_{s 1}\right) \ldots \ldots \ldots \ldots
\end{aligned}
$$




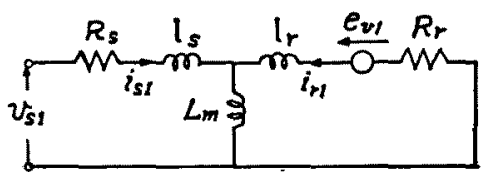

第 1 図 瞬時値正相分等価回路

Fig. 1. Instantaneous-positive-sequence equivalent circuit.

但し， $L_{s}=l_{s}+L_{m}, L_{r}=l_{r}+L_{m}$ であり, $e_{v 1}$ は速 度起電力， $\omega_{m}$ は回転子の電気角速度市よび $P$ は $d / d t$ を表わしている。

$\langle 2 \cdot 3\rangle$ 過渡電流 $\quad(1) \sim(3)$ 式を整理し, $i_{s 1}$, $i_{r 1}$ をラプラス変換 $[\mathcal{L}] し た I_{s 1}, I_{r 1}$ を求めると.

$$
\begin{aligned}
I_{s 1}= & {\left[( V _ { s 1 } + L _ { m } i _ { r 1 0 } + L _ { s } i _ { s 1 0 } ) \left\{R_{r}\right.\right.} \\
& \left.+\left(s-j \omega_{m}\right) L_{r}\right\}-\left(L_{r} i_{r 10}\right. \\
& \left.\left.+L_{m} i_{s 10}\right) s L_{m}\right] / \Delta(s) \ldots \ldots \ldots \ldots \ldots(4) \\
I_{r 1}= & {\left[\left(L_{m} i_{s 10}+L_{r} i_{r 10}\right)\left(R_{s}+s L_{s}\right)-\left(V_{s 1}\right.\right.} \\
& \left.\left.+L_{s} i_{s 10}+L_{m} i_{r 10}\right)\left(s-j \omega_{m}\right) L_{m}\right] / \Delta(s)
\end{aligned}
$$

$$
\Delta(s)=\left(L_{s} L_{r}-L_{m}^{2}\right)\left(s-\lambda_{1}\right)\left(s-\lambda_{2}\right) \quad \ldots(6)
$$

但し，澺字0は初期值を表わし， $V_{s 1}$ は $\mathcal{L}\left[v_{s 1}\right]$ を 示す。また， $\lambda_{1}, \lambda_{2}$ は $\Delta(s)=0$ の根であり，

$$
\begin{gathered}
\lambda_{1}, \lambda_{2}=\frac{1}{2}\left\{-\frac{L_{s} R_{r}+L_{r} R_{s}}{L_{s} L_{r}-L_{m}^{2}}+j \omega_{m}\right. \\
\pm \sqrt{\left.\left(\frac{L_{s} R_{r}+L_{r} R_{s}}{L_{s} L_{r}-L_{m}^{2}}-j \omega_{m}\right)^{2}-\frac{4 R_{s}\left(R_{r}-j \omega_{m} L_{r}\right)}{L_{s} L_{r}-L_{m}^{2}}\right\}}
\end{gathered}
$$

ここで, $\lambda_{1}=-\alpha_{1}+j \beta_{1}, \lambda_{2}=-\alpha_{2}+j \beta_{2}$ とおくと,

$$
\begin{aligned}
\alpha_{1}, \alpha_{2} & =\frac{1}{2}\left[\frac{L_{s} R_{r}+L_{r} R_{s}}{L_{s} L_{r}-L_{m}^{2}}\right. \\
\mp & \left.\sqrt{\frac{1}{2}\left(V \overline{A^{2}+B^{2}}+A\right)}\right] \ldots \ldots \ldots \ldots . . \\
\beta_{1}, \beta_{2} & =\frac{1}{2}\left[\omega_{m} \mp \sqrt{\frac{1}{2}\left(V \overline{A^{2}+B^{2}}-A\right)}\right]
\end{aligned}
$$

$$
\begin{gathered}
A=\left(\frac{L_{s} R_{r}+L_{r} R_{s}}{L_{s} L_{r}-L_{m}^{2}}\right)^{2}-\frac{4 R_{s} R_{r}}{L_{s} L_{r}-L_{m}^{2}}-\omega_{m}^{2} \\
\ldots \ldots \ldots \ldots \ldots \ldots \ldots \ldots \ldots \ldots \ldots \ldots \ldots \ldots \ldots \ldots \ldots \ldots \ldots \ldots \ldots \ldots \\
B=
\end{gathered}
$$

ここで， $V_{s 1}$ と固定子扣よび回転子正相電流の初期值 $i_{s 10}, i_{10}$ を求める。再投入相電圧の実効值を $V_{1}$ ， そ の角周波数を $\omega$ 於よび投入電圧の初期位相を $\xi$ とす ると,

$$
V_{s 1}=\sqrt{\frac{3}{2}} V_{1} e^{j \xi} \frac{1}{s-j \omega}
$$

よなる。再投入直前は電源が開放されている状態なの で,

$$
i_{s 10}=0
$$

である。次に $i_{r 10}$ を求める。再投入前の $i_{r 1}$ は戊留 電圧を発生させる要因であり，残留電圧を考慮するた めには，まずての電流について検討する必要がある。 ここで，電源開放時を基準にとった時間を $t^{\prime}$ とする。 残留電圧は，回転速度に比例した周波数の交流電圧で 古り，電気的時定数に比較して機械的時定数が大きい ために，ほぼ二次開路時定数 $L_{r} / R_{r}$ に従って減哀す

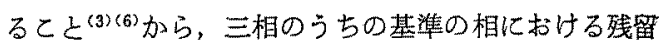
電圧の瞬時值 $e_{a}$ は

$$
\begin{aligned}
e_{a}= & \sqrt{2} E(1-S) e^{-\left(R_{r} / L_{r}\right) t^{\prime}} \cos \left\{(1-S) \omega^{\prime} t^{\prime}\right. \\
& \left.+\varphi^{\prime}\right\} \quad \ldots \ldots \ldots \ldots \ldots \ldots \ldots \ldots \ldots \ldots \ldots \ldots \ldots \ldots \ldots \ldots \ldots \ldots \ldots \ldots \ldots \ldots
\end{aligned}
$$

と表わせる。但し， $S$ はすべりであり，Eおよび はそれぞれ，開放前の電源電圧の実効值と角周波数で ある。また， $\varphi^{\prime}$ は残留電圧の初期位相である。残留 電圧は回転子電流により発生したすのであり，ことで 二次基準相の電流を $i_{r a}$ とすると,

$$
L_{m} \frac{d i_{r a}}{d t^{\prime}}=e_{\alpha}
$$

が成立する。従って，てれを解くと，

$$
\begin{gathered}
i_{r a}=\frac{\sqrt{2} E(1-s)}{L_{m}} e^{-\left(R_{r} / L_{r}\right) t^{\prime}} \\
\times \frac{\left[\left(-R_{r} / L_{r}\right) \cos \left(\omega_{m} t^{\prime}+\varphi^{\prime}\right)+\omega_{m} \sin \left(\omega_{m} t^{\prime}+\varphi^{\prime}\right)\right]}{\left(R_{r} / L_{r}\right)^{2}+\omega_{m}^{2}}
\end{gathered}
$$

但し， $(1-s) \omega^{\prime}=\omega_{m}$ である。こてで， $t^{\prime}$ は残留電 壬繼続期間内の比較的短い時間であり， $R_{r} / L_{r}$ む $\omega_{m}$ 飞比較し，十分小さいので，

$$
i_{r a}=\frac{\sqrt{2} E(1-s)}{\omega_{m} L_{m}} e^{-\left(R_{r} / L_{r}\right) t^{\prime}} \sin \left(\omega_{m} t^{\prime}+\varphi^{\prime}\right)
$$

と近做できる。 $i_{r a}$ を正相分電流 $i_{r 1}$ 亿変換すると,

$$
i_{r 1}=\sqrt{\frac{3}{2}} \frac{E_{0}}{\omega_{m} L_{m}} e^{j\left(\omega_{m} t^{\prime}+\varphi^{\prime}-\pi / 2\right)}
$$

が得られる。但し， $E_{0}=E(1-S) e^{-\left(R_{r} / L_{r}\right) t^{\prime}}$ である。 以上で $i_{r 1}$ が求まったので，てれより $i_{r 10}$ が求められ る。すなわち，再投入時の時刻 $t^{\prime}$ 之すべり $S$ 上り， まず $E_{0}$ が得られる。次に(18)式において $t^{\prime}$ を新た に再投入時を基準とした時間 $t$ 亿置き換え, 更に, $t$ =0とすると，

$$
i_{r^{\prime} 10}=\sqrt{\frac{3}{2}} \frac{E_{0}}{\omega_{m} L_{m}} e^{j(\varphi-\pi / 2)}
$$

但し， $\varphi$ は再投入時を基準とした場合の残留電圧の 
初期位相である。(6)式〜 (13) 式および (19)式の関係 を用いて，(4)式，(5)式を逆变換し， $i_{s 1}$ および $i_{r 1}$ を求めると

$$
\begin{aligned}
& i_{s 1}=\sqrt{\frac{3}{2}} \delta\left[V _ { 1 } e ^ { j \xi } \left(\frac{R_{r} / L_{r}}{\left\{\alpha_{1}+j\left(\omega-\beta_{1}\right)\right\}\left\{\alpha_{2}\right.}\right.\right. \\
& \frac{+j\left(\omega-\omega_{m}\right)}{+j\left(\omega-\beta_{2}\right\}} e^{j \omega t} \\
& +\frac{R_{r} / L_{r}-\alpha_{1}+j\left(\beta_{1}-\omega_{m}\right)}{\left\{-\alpha_{1}+j\left(\beta_{1}-\omega\right)\right\}\left\{\left(\alpha_{2}-\alpha_{1}\right)+j\left(\beta_{1}-\beta_{2}\right)\right\}} \\
& \times e^{\left(-\alpha_{1}+j \beta_{1}\right) t} \\
& +\frac{R_{r} / L_{r}-\alpha_{2}+j\left(\beta_{2}-\omega_{m}\right)}{\left\{-\alpha_{2}+j\left(\beta_{2}-\omega\right)\right\}\left\{\left(\alpha_{1}-\alpha_{2}\right)+j\left(\beta_{2}-\beta_{1}\right)\right\}} \\
& \left.\times e^{\left(-\alpha_{2}+j \beta_{2}\right) t}\right) \\
& +\frac{E_{0}}{\omega_{m}} e^{j(\varphi-\pi / 2)}\left(\frac{R_{r} / L_{r}-j \omega_{m}}{\alpha_{2}-\alpha_{1}+j\left(\beta_{1}-\beta_{2}\right)} e^{\left(-\alpha_{1}+j \beta_{2}\right) t}\right. \\
& \left.\left.+\frac{R_{r} / L_{r}-j \omega_{m}}{\alpha_{1}-\alpha_{2}+j\left(\beta_{2}-\beta_{1}\right)} e^{\left(-\alpha_{2}+j \beta_{2}\right) t}\right)\right] \\
& i_{r 1}=\sqrt{\frac{3}{2}} \delta\left[\frac{L_{m}}{L_{r}} V_{1} e^{j_{\xi}}\right. \\
& \times\left(\frac{j\left(\omega_{m}-\omega\right)}{\left\{\alpha_{1}+j\left(\omega-\beta_{1}\right)\right\}\left\{\alpha_{2}+j\left(\omega-\beta_{2}\right)\right\}} e^{j \omega t}\right. \\
& +\frac{\alpha_{1}-j\left(\beta_{1}-\omega_{m}\right)}{\left\{\left(\alpha_{2}-\alpha_{1}\right)+j\left(\beta_{1}-\beta_{2}\right)\right\}\left\{-\alpha_{1}+j\left(\beta_{1}-\omega\right)\right\}} \\
& \times e^{\left(-\alpha_{1}+j \beta_{1}\right) t} \\
& +\frac{\alpha_{2}-j\left(\beta_{2}-\omega_{m}\right)}{\left.\left\{\alpha_{1}-\alpha_{2}\right)+j\left(\beta_{2}-\beta_{1}\right)\right\}\left\{-\alpha_{2}+j\left(\beta_{2}-\omega\right)\right\}} \\
& \left.\times e^{\left(-\alpha_{2}+j \beta_{2}\right) t}\right) \\
& +\frac{E_{0}}{\omega_{m} L_{m}} e^{j(\varphi-\pi / 2)}\left\{\frac{R_{s}+L_{s}\left(-\alpha_{1}+j \beta_{1}\right)}{\alpha_{2}-\alpha_{1}+j\left(\beta_{1}-\beta_{2}\right)} e^{\left(-\alpha_{1}+j \beta_{1}\right) t}\right. \\
& +\frac{R_{s}+L_{s}\left(-\alpha_{2}+j \beta_{2}\right)}{\alpha_{1}-\alpha_{2}+j\left(\beta_{2}-\beta_{1}\right)} e^{\left(-\alpha_{2}+j \beta_{2}\right) t} \\
& -\frac{L_{m}^{2}}{L_{r}}\left(\frac{-\alpha_{1}+j\left(\beta_{1}-\omega_{m}\right)}{\alpha_{2}-\alpha_{1}+j\left(\beta_{1}-\beta_{2}\right)} e^{\left(-\alpha_{1}+j \beta_{1}\right) t}\right. \\
& \left.\left.\left.+\frac{-\alpha_{2}+j\left(\beta_{2}-\omega_{m}\right)}{\alpha_{1}-\alpha_{2}+j\left(\beta_{2}-\beta_{1}\right)} e^{\left(-\alpha_{2}+j \beta_{2}\right) t}\right)\right\}\right] .
\end{aligned}
$$

但し, $\delta=L_{r} /\left(L_{s} L_{r}-L_{m}^{2}\right)$ であり， $i_{s 1}, i_{+1}$ は瞬 時值正相分電流であるから，これより一次および二次 の基準の相における電流 $i_{s}, i_{r}$ は，

$$
i_{s}=\frac{2}{\sqrt{3}} R_{e}\left(i_{s 1}\right), \quad i_{r}=\frac{2}{\sqrt{3}} R_{e}\left(i_{r 1}\right) \ldots
$$

の関係を用いて変換すれば求められる。但し，Reは 実部を表わす。往って，

$$
\begin{aligned}
i_{s}= & \sqrt{2} \delta\left(V_{1}\left\{\eta_{1} \cos (\omega t+\xi)-\eta_{2} \sin (\omega t+\xi)\right\}\right. \\
& +\left(V_{1}\left\{\eta_{3} \cos \left(\beta_{1} t+\xi\right)-\eta_{4} \sin \left(\beta_{1} t+\xi\right)\right\}\right.
\end{aligned}
$$

$+\left(E_{0} / \omega_{m}\right)\left\{\eta_{7} \cos \left(\beta_{1} t+\varphi-\pi / 2\right)\right.$

$\left.\left.-\eta_{8} \sin \left(\beta_{1} t+\varphi-\pi / 2\right)\right\}\right] e^{-\alpha_{1} t}$

$+\left[V_{1}\left\{\eta_{5} \cos \left(\beta_{2} t+\xi\right)-\eta_{6} \sin \left(\beta_{2} t+\xi\right)\right\}\right.$

$-\left(E_{0} / \omega_{m}\right)\left\{\eta_{7} \cos \left(\beta_{2} t+\varphi-\pi / 2\right)\right.$

$\left.\left.\left.-\eta_{8} \sin \left(\beta_{2} t+\varphi-\pi / 2\right)\right\}\right] e^{-\alpha_{2} t}\right)$

$i_{r}=V \overline{2} \delta\left(\frac{L_{m}}{L_{r}} V_{1}\left\{\eta_{10} \sin (\omega t+\xi)-\eta_{9} \cos (\omega t\right.\right.$

$+\xi)\}+\left[\frac{E_{0}}{\omega_{m} L_{m}}\left\{\eta_{15} \cos \left(\beta_{1} t+\varphi-\pi / 2\right)\right.\right.$

$\left.-\eta_{16} \sin \left(\beta_{1} t+\varphi-\pi / 2\right)\right\}$

$-\frac{L_{m}}{L_{r}} V_{1}\left\{\eta_{11} \cos \left(\beta_{1} t+\xi\right)-\eta_{12} \sin \left(\beta_{1} t\right.\right.$

$+\xi)\}-\frac{L_{m} E_{0}}{\omega_{m} L_{\tau}}\left\{\eta_{19} \cos \left(\beta_{1} t+\varphi-\pi / 2\right)\right.$

$\left.\left.-\eta_{20} \sin \left(\beta_{1} t+\varphi-\pi / 2\right)\right\}\right] e^{-\alpha_{1} t}$

$+\left[\frac{E_{0}}{\omega_{m} L_{m}}\left\{\eta_{17} \cos \left(\beta_{2} t+\varphi-\pi / 2\right)\right.\right.$

$\left.-\eta_{18} \sin \left(\beta_{2} t+\varphi-\pi / 2\right)\right\}$

$-\frac{L_{m}}{L_{T}} V_{1}\left\{\eta_{13} \cos \left(\beta_{2} t+\xi\right)-\eta_{14} \sin \left(\beta_{2} t\right.\right.$

$+\xi)\}-\frac{L_{m} E_{0}}{\omega_{m} L_{\tau}}\left\{\eta_{21} \cos \left(\beta_{2} t+\varphi-\pi / 2\right)\right.$

$\left.\left.\left.-\eta_{22} \sin \left(\beta_{2} t+\varphi-\pi / 2\right)\right\}\right] e^{-\alpha_{2} t}\right) \ldots$

亡なる。 $\eta_{1} \sim \eta_{22}$ は付第 1 表に示す。以上により，再 投入時の一次执よび二次の電流が求まった。これらの 式はある回転数における電流の式である。

〈2.4〉過渡トルク発生トルク $T$ は $(20)$ 式, (21)式を用いれば次式により求められる。

$$
T=-2 p I_{m}\left(L_{m} \bar{i}_{s 1} i_{r 1}\right)
$$

ここで,Tは瞬時值であり，pは極対数

を表わす。また, $i_{s 1}$ は $i_{s 1}$ の共役複素数を示し， $I_{m}$ 岵虚部を表わす。(25)式に(20)式および(21)式を代入 して整理すると，次式が得られる。

$$
\begin{aligned}
T= & -3 p L_{m} \delta^{2}\left(\left\{\left\{\frac{E_{0}}{\omega_{m} L_{m}}\left(K_{18}-\frac{L_{m}^{2}}{L_{r}} K_{22}\right)\right.\right.\right. \\
& \left.-\frac{L_{m}}{L_{r}} V_{1} K_{14}\right\}\left(V_{1} K_{3}+\frac{E_{0}}{\omega_{m}} K_{7}\right) \\
& -\left\{\frac{E_{0}}{\omega_{m} L_{m}}\left(K_{17}-\frac{L_{m}^{2}}{L_{r}}\right) K_{21}\right. \\
& \left.\left.-\frac{L_{m}}{L_{r}} V_{1} K_{13}\right\}\left(V_{1} K_{4}+\frac{E_{0}}{\omega_{m}} K_{8}\right)\right] e^{-2 \alpha_{1} t} \\
& +\left[\left\{\frac{E_{0}{ }^{*}}{\omega_{m} L_{m}}\left(K_{20}-\frac{L_{m}{ }^{2}}{L_{r}} K_{24}\right)\right.\right.
\end{aligned}
$$




$$
\begin{aligned}
& \left.-\frac{L_{m}}{L_{r}} V_{1} K_{16}\right\}\left(V_{1} K_{5}+\frac{E_{0}}{\omega_{m}} K_{9}\right) \\
& -\left\{\frac{E_{0}}{\omega_{m} L_{m}}\left(K_{19}-\frac{L_{m}^{2}}{L_{r}} K_{23}\right)\right. \\
& \left.\left.-\frac{L_{m}}{L_{r}} V_{1} K_{15}\right\}\left(V_{1} K_{6}+\frac{E_{0}}{\omega_{m}} K_{10}\right)\right] e^{-2 \alpha_{2} t} \\
& +\left[\left\{\frac{E_{0}}{\omega_{n n} L_{m}}\left(K_{20}-\frac{L_{m}^{2}}{L_{r}} K_{24}\right)\right.\right. \\
& \left.-\frac{L_{m}}{L_{T}} V_{1} K_{16}\right\}\left(V_{1} K_{3}+\frac{E_{0}}{\omega_{m}} K_{7}\right) \\
& +\left\{\frac{E_{0}}{\omega_{m} L_{m}}\left(K_{18}-\frac{L_{m}^{2}}{L_{r}} K_{22}\right)\right. \\
& \left.-\frac{L_{m}}{L_{r}} V_{1} K_{14}\right\}\left(V_{1} K_{5}+\frac{E_{0}}{\omega_{m}} K_{9}\right) \\
& -\left\{\frac{E_{0}}{\omega_{m} L_{m}}\left(K_{17}-\frac{L_{m}^{2}}{L_{r}} K_{21}\right)\right. \\
& \left.-\frac{L_{m}}{L_{r}} V_{1} K_{13}\right\}\left(V_{1} K_{6}+\frac{E_{0}}{\omega_{m}} K_{10}\right) \\
& -\left\{\frac{E_{0}}{\omega_{m} L_{m}}\left(K_{19}-\frac{L_{m}^{2}}{L_{r}} K_{23}\right)\right. \\
& \left.\left.-\frac{L_{m}}{L_{r}} V_{1} K_{15}\right\}\left(V_{1} K_{4}+\frac{E_{0}}{\omega_{m}} K_{8}\right)\right] e^{-\left(\alpha_{1}+\alpha_{2}\right) t} \\
& +\left[\frac { E _ { 0 } V _ { 1 } } { \omega _ { m } L _ { m } } \left\{\left(K_{18}-\frac{L_{m}^{2}}{L_{r}} K_{22}\right) K_{1}-\left(K_{17}\right.\right.\right. \\
& \left.\left.-\frac{L_{m}^{2}}{L_{\tau}} K_{21}\right) K_{2}\right\}+\frac{L_{m}}{L_{r}} V_{1}^{2}\left(K_{2} K_{13}+K_{4} K_{13}\right. \\
& \left.-K_{1} K_{14}-K_{3} K_{12}\right)+\frac{L_{m} E_{0} V_{1}}{\omega_{m} L_{\tau}}\left(K_{8} K_{11}\right. \\
& \left.\left.-K_{7} K_{12}\right)\right] e^{-\alpha_{1} t}+\left[\frac { E _ { 0 } V _ { 1 } } { \omega _ { m } L _ { m } } \left\{\left(K_{20}\right.\right.\right. \\
& \left.\left.-\frac{L_{m}^{2}}{L_{\tau}} K_{24}\right) K_{1}-\left(K_{19}-\frac{L_{m}^{2}}{L_{r}} K_{23}\right) K_{2}\right\} \\
& +\frac{L_{m}}{L_{\tau}} V_{1}^{2}\left(K_{2} K_{15}+K_{6} K_{11}-K_{1} K_{16}\right. \\
& \left.\left.-K_{5} K_{12}\right)+\frac{L_{m} E_{0} V_{1}}{\omega_{m} L_{r}}\left(K_{10} K_{11}-K_{9} K_{12}\right)\right] \\
& \left.\times e^{-\alpha_{2} t}+\frac{L_{m}}{L_{r}} V_{1}^{2}\left(K_{2} K_{11}-K_{1} K_{12}\right)\right)
\end{aligned}
$$

但し， $K_{1} \sim K_{24}$ は付第 2 表に示すとおりである。 (26)式は，ある回転数们ける発生トルクを示す式で あり, 本研究では電気, 機械的過渡状態を対象として いるので， $\omega_{m}$ は逐次変化する。従って，この場合の トルクは次のように決定できる。すなわち，再投入直 前のトルクは零であるので，再投入時の最初の段階で はトルクを零として (27)式の運動方程式に代入し，
Runge-Kutta 法で数值計算するてとにより次ステッ プの $\omega_{m}$ を求める。この $\omega_{m}$ を(26)式代代入し，トル クを計算する。更に，トルクを再び(27)式に代入し， 以下, 同じ繰返し計算によって， $\omega_{m}$ が変化する場合 の時間任対する瞬時トルクが得ら机る。

$$
T=\frac{J}{p} \frac{d \omega_{m}}{d t}+\frac{D}{p} \omega_{m}+T_{L}
$$

ここで， $T_{L}$ は負荷卜ルクであり，J,Dはそれぞれ， 回転系の慣性モーメント抢よび制勘保数を示す。これ までに求的た(23)式，(24)式拈よび(26)式は〈2・1〉節 で述べた仮定の下では，大きな容量の電動機偪用す ることも可能である。

\section{3. 実測および解析結果}

〈3・1〉供試機およひ実測供試誘導電動機の定 格は，1.5 kW，200 V, 6.6 A, $50 \mathrm{~Hz}, 4$ 極で，回路 定数 ${ }^{(7)}$ は， $R_{s}=1.277 \Omega ， R_{r}=1.032 \Omega, l_{s}=l_{r}=0.0041$ $\mathrm{H}, L_{m}=0.0999 \mathrm{H}$ である。また，供試機目体の機械 的定数诂, $J=0.0070 \mathrm{Nms}^{2} / \mathrm{rad}^{2}, D=0.00073 \mathrm{Nms} / \mathrm{rad}$ であり，直流発電機を連結した状態では，J=0.084 $\mathrm{Nms}^{2} / \mathrm{rad}^{2}, D=0.0061 \mathrm{Nms} / \mathrm{rad}$ となる。可変周波電 源としては，10kVA で周波数を $10 \sim 100 \mathrm{~Hz}$ まで変 化できる三相同期発電機苦使用した。過渡トルクは磁 わい式トルク棓とリニアコーダを接続し，実測した。 更に，電流は各相に $0.1 \Omega$ のシャントをそう入し，そ のシャントの電生をリニアコーダに記録さ甘，回転速 度は直流発電機の出力電圧をりニアコーダで記録し た。電源の切換えは三相ナイフスイッチを用いた。第 2 図は $50 \mathrm{~Hz} 213 \mathrm{~V}$ 加 $30 \mathrm{~Hz} 120 \mathrm{~V}$ の電源に供試 機を再投入した場合の過渡特性の実測例であり，慣性 負荷として直流発電機を連結している状態である。以 後、計算および実測值はすべて直流発電機を連結した 状態における值である。また，第 2 困にも示してある 残留電代について，この電圧の減亭時定数は電源の周

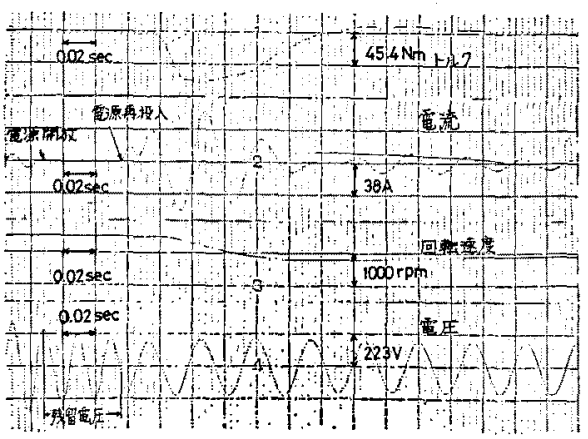

第 2 实測例

Fig. 2. An example of measurement. 
波数に無関係であることが明らかにされており(3)(6)， 供試㙨の場合，回路定数より減裹時定数は $L_{s} / R_{r}$ $=0.102 \mathrm{~s}$ である。なお，実測結果では $0.107 \mathrm{~s}$ であ り，計算值と実测值はほぼ一致した。

〈3.2〉解析結果亡実測結果の比較 前章では残 留電王を考慮した電流およびトルクの式を導出し，数 式的な㭘討を可能にした。本節では，乙れらの式の妥 当座を確加めるたかに解析結果と実測結果の比較を行 なう。なお，(25)式加らも明ら加なように，過渡トル クの罗当性を確加ることにより過渡電流の正しさむ 確かめられることになるので，ここでは，過渡トルク についてのみ比較することにする。第 3 図は $50 \mathrm{~Hz}$ $213 \mathrm{~V}$ から $30 \mathrm{~Hz} 120 \mathrm{~V}$ に電動機を再投入した揚合 の迵渡トルク特性を示す。但し，電源を開放㣪，再投 入するまでの時間 $t_{s}$ は $0.042 \mathrm{~s}$ である。また，第 4 図住， $50 \mathrm{~Hz} 213 \mathrm{~V}$ 加ら $70 \mathrm{~Hz} 280 \mathrm{~V}$ に $t_{s}=0.044$ sで再投入した場合の過渡トルク特性である。以上の 場合，任意の時間に霓源から電動機を開放し，任意の

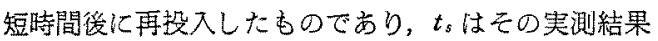
より得られた時間である。従って，解析結果は実測の

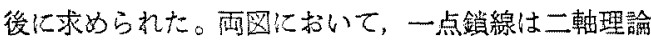
を用いてシミニレーションを行なった結果 ${ }^{(8)}$ であり， 破線は本解析結果である。とれらの結果の比較より， シミニレーション拈よび本解析結果の両者共，実测徊 に比翰的良く一致し，本論文で行なった過渡トルク括 よび過渡電流の解析加妥当性を持つことが確かめられ た。

\section{4. 検 討}

本章では解析おより゙実测結果より，残留電圧継続期 聞内での，可变周波電源への再投入時に扔ける電動機 の過洨トル多特性を中心に述べる。また，ここでは， 電源開放前の周波数より香（1）低心周波数の電源， および (2) 高い周波数の䨖源に再投入する場合に分 類して検討する。

〈4·1〉過渡トルク波形およひ $\boldsymbol{J}$ の影響（1）の 場合，第3图より再祋入直後，負の大きなトルクを発 生するここがわかる。これは，再投入直後には回転速 度が同期速度り上の期間があり，電動機が発電機领域 の動作特性を示劣ためで䒛る。第 5 図は，Jを種々変 化して $50 \mathrm{~Hz} 213 \mathrm{~V}$ 加ら $30 \mathrm{~Hz} 120 \mathrm{~V}$ に $t_{s}(0.043$ s), $\varphi$ および $\xi$ を一定にして，再投入した昜合の過渡 トルク扣よび回転速度の計算結果である。同図より， Jが大きくなると，再投入直後の負トルクが発生して いる時間は長くなり，同時化ある程度まで過渡最大卜 ルクが大きくなること屯わかる。また，Jが小さいほ

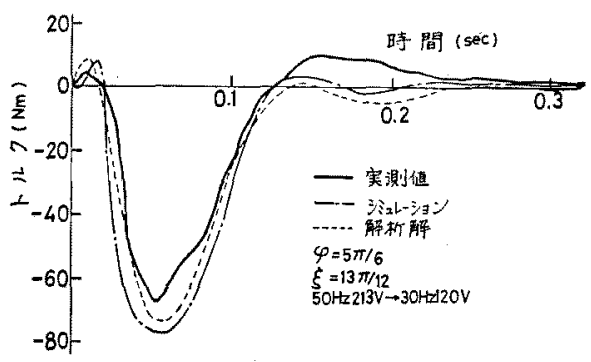

第 3 図 実測值亡計算値の比較

Fig. 3. Comparison of measured and calculated results.

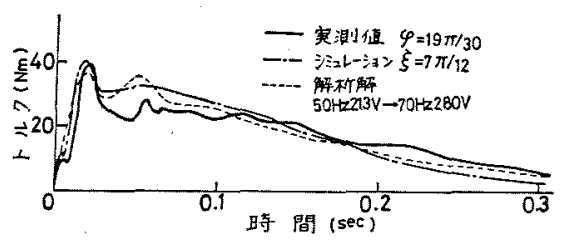

第 4 図 実測值之計䍩值の比較

Fig, 4. Comparison of measured and calculated results.

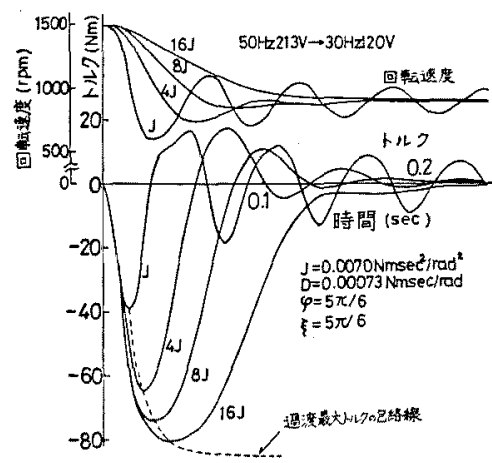

第 5 図 過湶トルク抢よび回転速度特性に 及佂す $J$ の影響

Fig. 5. Effects of inertia moment on transient torque and speed characteristics.

ぞトルクの振動回数が增加することも明らかになっ た。（2）の場合，第4図に示す波形上なるが，乙の場 合は電動機領域の動作状態である。後述するが，再投 入直後，鱼の過渡トルクを発生する場合もある。第 6 図仗，Jを種々変化して $50 \mathrm{~Hz} 213 \mathrm{~V}$ 加ら $70 \mathrm{~Hz} 280$ Vに $t_{s}=0.044 \mathrm{~s}$ で再投入した場合の過渡トルクお よび回転速度の計算結果を示している。この結果は、 正の過渡最大トルクがルの影響党はとんど受りないこ と走している。

$\langle 4 \cdot 2\rangle$ 再投入電圧位相 $\xi$ および電源の周波数が過 度トルク特性に及ばす影響（1）の場合の列として 第 7 図に， $50 \mathrm{~Hz} 213 \mathrm{~V}$ から $t_{s}=0.013 \mathrm{~s}$ で $40 \mathrm{~Hz}$ 


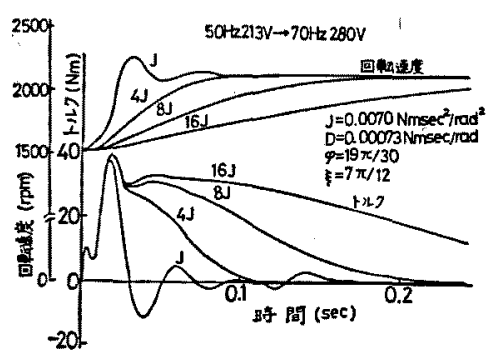

第 6 図 過渡トルクおよび回転速度特性に 及祦す Jの影響

Fig. 6. Effects of inertia moment on transient torque and speed characteristics.

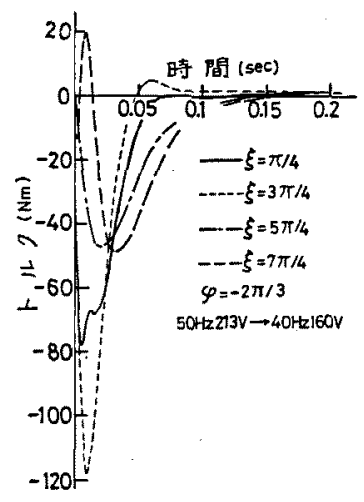

第 7 図 過渡トルク特性

Fig. 7. Transient torque characteristics. $160 \mathrm{~V}$ 江再投入した場合の過渡トルクの計算結果を示 す。四中に示すように，乡の影響をみるため，再投入 時に招ける残留電生の初期位相 $\varphi$ を $-2 \pi / 3$ に固定 している。過渡最大トルク $T_{\max }$ の最大值は最小值の 約 3 倍近くまで達して捄り，ほは $T_{\max }$ 亿著しい影響 を及ぼす。（2）の場合の例としては，第 8 図に $50 \mathrm{~Hz}$ $213 \mathrm{~V}$ から $70 \mathrm{~Hz} 280 \mathrm{~V}$ に $t_{s}=0.012 \mathrm{~s}$ で再投入し た埸合の計算結果を示す。再投入直後の負の過渡トル クはほの影響を著しく受けるが，正の最大トルクは

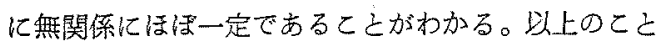
より，場合によっては定格トルクの十倍程度の過渡卜 ルクが発生することああり，再投入のひん度があまり 汇多いと，電動機軸の機械的强度に問題を生じる場合 があると考えられる。

雪源開放前の周波数在 $f_{1}$, 再投入後の周波数索 $f_{2}$ として， $f_{1}, f_{2}$ 拈よびその比を種々变えて多くの実 湘および解析を行なった。その結果，任意の慣性を負 う笔動機の再投入に扔いて， $f_{2} / f_{1}$ が 0.8 程度では, 徉来諭じられてきた同一電源 $\left(f_{2} / f_{1}=1\right)$ の再投入に おりる場合の上うに， $\varphi$ 上の位相関係により $T_{\max }$ は著しく变化する。しかし， $f_{2} / f_{1}$ 加 0.4 程度以下

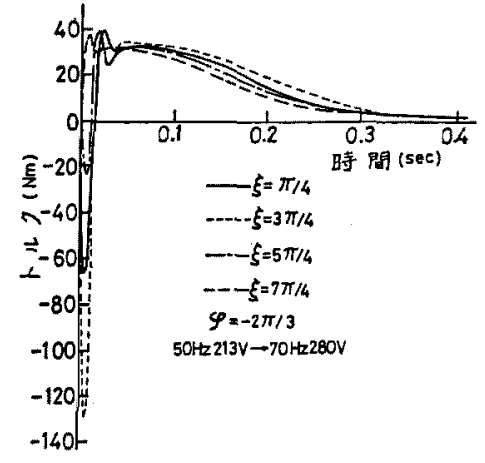

第 8 図 過渡トルク特性

Fig. 8. Transient torque characteristics.

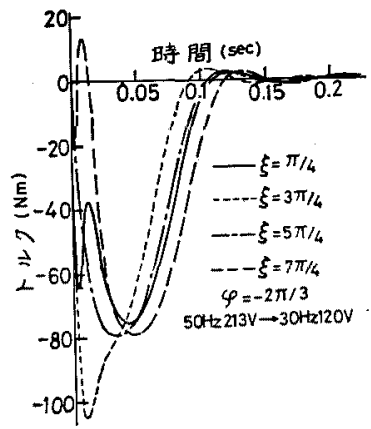

第 9 図 過渡卜ルク特性

Fig 9 Transient torque characteristics.

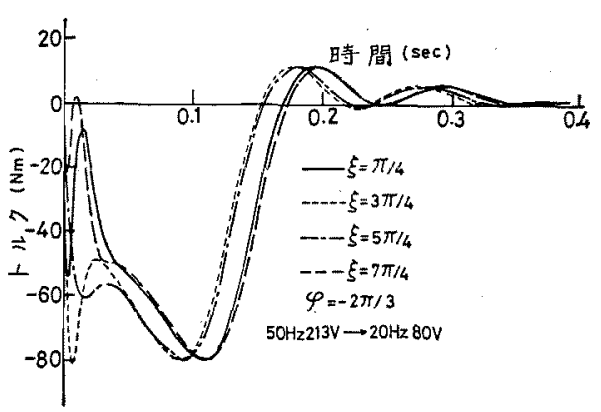

第 10 図 過渡卜ルク特性

Fig. 10. Transient torque characteristics.

では，当は $T_{\max }$ にほとんど影響を与えないととが明 らか放なった。更に，ある慣性を負う電動機の再投入 に扔いて，任意の $t_{s}$ に対し， $f_{2} / f_{1}$ が 1 から大きく はずれるほど過渡トルクの振動回数が増加する。また 定常トルクに到る時間，すなわち過渡状態が継続する 期間が長くなるととも明らかになった。以上のととは 例として挙げた第 7 図，更に第 9 図および第 10 図に 顕著に現われている。第 9 図および第 10 図は，50 $\mathrm{Hz} 213 \mathrm{~V}$ から $t_{\mathrm{s}}=0.013 \mathrm{~s}$ でそれぞれ $30 \mathrm{~Hz} 120 \mathrm{~V}$ 招よび $20 \mathrm{~Hz} 80 \mathrm{~V}$ に再投入した場合の過渡トルクの 


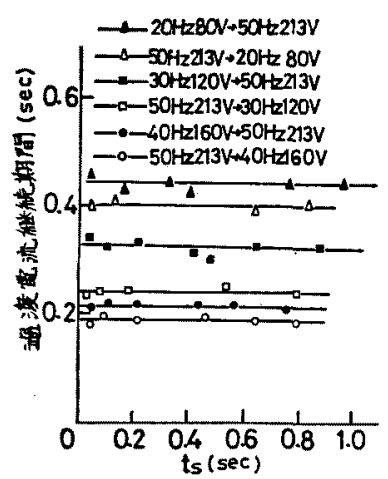

第 11 因過渡電流継続期間

Fig. 11. Duration of transient current.

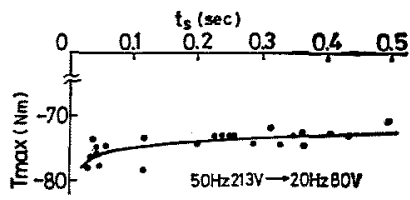

第 12 図 $t_{s}$ 之 $T_{\max }$ の関係

F.g. 12. Relation between $t_{s}$ and $T_{\max }$.

計算結果である。

第 7 図 第 10 図の各図より，過渡状態継続期間は

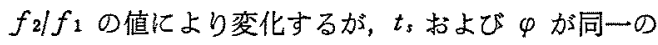

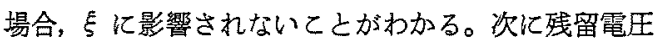
が存在している期間に扰いて，種々の周波数の電源に 供試機を再投入した場合，過渡電流が定常電流に到る までの時間を実測より求めた結果を第 11 図に示す。 同図上り，ある慣性を負う電動機をある周波数の電源 に再投入した場合，過渡状態継䊦期間は $t s$ ，すなわち 残留電壬に関係なく同じであることがわかる。以上の ことより，直る慣性を負う電動機をある周波数の電源 に再投入する場合，その過渡状態継続期間は残留電圧 の大きさおよびその位相 $\varphi$ ともには無関係とな り， $f_{2} / f_{1}$ だけの関数になることが明らかになった。

〈4.3〉 残留電圧と $\boldsymbol{T}_{\max }$ の関係＼cjkstart実測および計 算に際し，任意の $t_{s}$ で可変周波電源们再投入した場 合には，再投入時の残留電圧の位相之投入電圧の位相 関係が任意となり，投入条件が相達するため，乙の場 合の残留電生と $T_{\mathrm{max}}$ の関係を諭じることはむずかし い。そこで (1) の例として $50 \mathrm{~Hz} 213 \mathrm{~V}$ から 20 $\mathrm{Hz} 80 \mathrm{~V}$ に再投入した場合について检討する。この 場合は，睡に〈4・2〉節および第 10 図に示したように

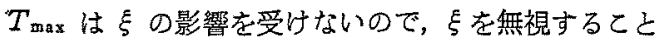
ができる。第 12 図は多数の実測結果より $t_{s} と T_{\max }$ の関係を表わしたものである。その結果， $t_{s}$ が短いほ
第 1 表 $t$ 。 $T_{\max }$ の関係

Table 1. Relation between $t_{s}$ and $T_{\max }$.

\begin{tabular}{|c|c|c|c|c|c|}
\hline$t_{s}(\mathrm{~s})$ & 0.018 & 0.058 & 0.12 & 0.20 & 0.49 \\
\hline$T_{\max }(\mathrm{Nm})$ & 38.0 & 38.4 & 38.7 & 39.5 & 39.8 \\
\hline 残留電王(V) & 229 & 153 & 83.8 & 37,1 & 1.86 \\
\hline
\end{tabular}

よ゙すすなわち，残留電生が大きいほど $T_{\max }$ は大きく なる傾向を示すととが明らかになった。（2）の例とし て $\varphi$ を $-\pi / 6 ， \xi$ を $\pi / 4$ に固定し，再投入時の残留 電任之段入電任の位相条件を同じにして $50 \mathrm{~Hz} 213 \mathrm{~V}$ 加 $70 \mathrm{~Hz} 280 \mathrm{~V}$ に再投入した。そのときの $t_{s}$ すな わち，残留電圧の大きさを変化した場合の $T_{\max }$ につ いて, 計算結果より求めた值を第 1 表に示す。それに よると $t_{s}$ が長いほど，すなわち残留電纴が小さいほ ど $T_{\max }$ はわずかながら大きくなる傾向を示した。

\section{5.むすひ}

運転中にお方誘導電動機の可変周波電源への再投 入に上る過渡電流，および過渡トルクについて，瞬時 值対称座標法により解析を行なった。導出したトルク 式と運動方程式を用いて，逐次変化する回転速度に対 応した過渡トルクが得られた。こうして求められた解 析結果㧍よび二軸理論による解析結果は, 実測結果仪 比較的良く一致し，本解析結果が妥当であることを確 認できた。更に解析および実測結果を用いて，主に過 渡トルク特性について検討した。その結果を要約する と.

(1) 開放前の電源の周波数を $f_{1}$, 再投入後の周 波数を $f_{2}$ とした場合， $f_{2} / f_{1}<1$ では負荷を含む慣 性ニーメントJが大きくなると, 再投入直後の負トル クの発生している時間は長くなり，過渡最大トルクは ある程度まで大きくなる。また，Jが小さくなると， トルクの振動回数が增加方。次化 $f_{2} / f_{1}>1$ では正 の過渡最大トルクはJの影響をはとんど受けない。

（2）任意の慣性を負う電動機の再投入において, $f_{2} / f_{1}$ が 0.4 程度以下では再投入電圧位相 $\xi$ は, 過 渡最大トルク $T_{\max }$ に影響を及ぼさない。

（3）古る慣性を負う電動機を電源開放後，再投入 までの任意の時間 $t_{s}$ で再投入する場合， $f_{2} / f_{1}$ が 1 から大きくはずれるに伴って, 過渡トルクの振勳回数 は增加し，過渡状態継䊦期間は長くなる。更にある慣 性を負う電勤機をある周波数の電源化再投入する場 合，その過渡状態継続期間は残留電圧の大きさおよび その位相 $\varphi$ 己 $\xi$ には無関係であり, $f_{2} / f_{1}$ だけの関 数となる。

(4) $t_{s}$ ，すなわち残留電圧の大きさと $T_{\max }$ の関 係は， $f_{2} / f_{1}<1$ では $t_{s}$ が短いはよ゙， $f_{2} / f_{1}>1$ では 
付第 1 表 䉓流の係数

app. Table 1. Coefficient of current.

\begin{tabular}{|c|c|}
\hline 係数 & 俰数の内容 \\
\hline$\eta_{1}$ & $\begin{array}{c}{\left[\left(R_{r} / L_{r}\right)\left\{\alpha_{1} \alpha_{2}-\left(\omega-\beta_{1}\right)\left(\omega-\beta_{2}\right)\right\}+\left(\omega-\omega_{m}\right)\left(\alpha_{1}\left(\omega-\beta_{2}\right)\right.\right.} \\
\left.\left.+\alpha_{2}\left(\omega-\beta_{2}\right)\right\}\right] / \mu_{1}\end{array}$ \\
\hline$\eta_{2}$ & $\begin{array}{l}{\left[\left(\omega-\omega_{m}\right)\left\{\alpha_{1} \alpha_{2}-\left(\omega-\beta_{1}\right)\left(\omega-\beta_{2}\right\}-\left(R_{r} / L_{r}\right)\left\{\alpha_{1}\left(\omega-\beta_{2}\right)\right.\right.\right.} \\
\left.\left.\quad+\alpha_{2}\left(\omega-\beta_{1}\right)\right\}\right] / \mu_{1}\end{array}$ \\
\hline$\eta_{3}$ & $\begin{aligned} & {\left[\left(R_{r} / L,-\alpha_{1}\right)\left\{\left(\alpha_{1}-\alpha_{2}\right) \alpha_{1}-\left(\beta_{1}-\omega\right)\left(\beta_{1}-\beta_{2}\right)\right\}\right.} \\
&\left.+\left(\beta_{1}-\omega_{m}\right)\left(\left(\beta_{1}-\omega\right)\left(\alpha_{2}-\alpha_{1}\right)-\left(\beta_{1}-\beta_{2}\right) \alpha_{1}\right)\right] / \mu_{2}\end{aligned}$ \\
\hline$\eta_{4}$ & $\begin{array}{l}{\left[\left(\beta_{1}-\omega_{m}\right)\left\{\left(\alpha_{1}-\alpha_{2}\right) \alpha_{1}-\left(\beta_{1}-\omega\right)\left(\beta_{1}-\beta_{2}\right)\right\}\right.} \\
\left.\quad-\left(R_{r} / L_{r}-\alpha_{1}\right)\left\{\left(\beta_{1}-\omega\right)\left(\alpha_{2}-\alpha_{1}\right)-\left(\beta_{1}-\beta_{2}\right) \alpha_{1}\right\}\right] / \mu_{2}\end{array}$ \\
\hline$\eta_{6}$ & $\begin{aligned} {\left[\left(R_{r} / L,\right.\right.} & \left.-\alpha_{2}\right)\left\{\alpha_{2}\left(\alpha_{2}-\alpha_{1}\right)-\left(\beta_{2}-\omega\right)\left(\beta_{2}-\beta_{1}\right)\right\} \\
& \left.+\left(\beta_{2}-\omega_{m}\right)\left\{\left(\beta_{2}-\omega\right)\left(\alpha_{1}-\alpha_{2}\right)-\alpha_{2}\left(\beta_{2}-\beta_{1}\right)\right]\right] \mu_{3}\end{aligned}$ \\
\hline$\eta_{6}$ & $\begin{array}{l}{\left[\left(\beta_{2}-\omega_{m}\right)\left\{\alpha_{2}\left(\alpha_{2}-\alpha_{1}\right)-\left(\beta_{2}-\omega\right)\left(\beta_{2}-\beta_{1}\right)\right\}\right.} \\
\left.\left.\quad-\left(R_{r} / L_{r}-\alpha_{2}\right)\left\{\beta_{2}-\omega\right)\left(\alpha_{1}-\alpha_{2}\right)-\alpha_{2}\left(\beta_{2}-\beta_{1}\right)\right\}\right] / \mu_{3}\end{array}$ \\
\hline$\eta_{2}$ & $\left.\left[R_{r} / L_{r}\right)\left(\alpha_{2}-\alpha_{1}\right)-\omega_{m}\left(\beta_{1}-\beta_{2}\right)\right] / \mu_{4}$ \\
\hline$\eta_{\mathrm{a}}$ & {$\left[\omega_{m}\left(\alpha_{1}-\alpha_{2}\right)+\left(R_{r} / L_{r}\right)\left(\beta_{2}-\beta_{1}\right)\right] / \mu_{4}$} \\
\hline$\eta_{s}$ & {$\left[\left(\omega-\omega_{m}\right)\left\{\alpha_{2}\left(\omega-\beta_{1}\right)+\alpha_{1}\left(\omega-\beta_{2}\right)\right\}\right] / \mu_{1}$} \\
\hline$\eta_{10}$ & {$\left[\left(\omega-\omega_{m}\right)\left\{\alpha_{1} \alpha_{2}-\left(\omega-\beta_{1}\right)\left(\omega-\beta_{2}\right)\right\}\right] / \mu_{1}$} \\
\hline$\eta_{11}$ & $\begin{array}{c}{\left[\alpha_{1} \mid\left(\beta_{1}-\beta_{2}\right)\left(\beta_{1}-\omega\right)-\alpha_{1}\left(\alpha_{1}-\alpha_{2}\right)\right\}+\left(\beta_{1}-\omega_{m}\right)\left(\alpha_{1}\left(\beta_{2}-\beta_{1}\right)\right.} \\
\left.+\left(\alpha_{2}-\alpha_{1}\right)\left(\beta_{1}-\omega\right)\right\} / \mu_{2}\end{array}$ \\
\hline$\eta_{12}$ & $\begin{array}{l}{\left[\left(\beta_{1}-\omega_{m}\right)\left\{\alpha_{1}\left(\alpha_{1}-\alpha_{2}\right)-\left(\beta_{1}-\beta_{2}\right)\left(\beta_{1}-\omega\right)\right\}\right.} \\
\left.\quad+\alpha_{1}\left(\alpha_{1}\left(\beta_{2}-\beta_{1}\right)+\left(\alpha_{2}-\alpha_{1}\right)\left(\beta_{1}-\omega\right)\right\}\right] / \mu_{2}\end{array}$ \\
\hline$\eta_{13}$ & $\begin{array}{l}{\left[\alpha_{2}\left\{\left(\beta_{2}-\beta_{1}\right)\left(\beta_{2}-\omega\right)-\alpha_{2}\left(\alpha_{2}-\alpha_{1}\right)\right\}\right.} \\
\left.\quad+\left(\beta_{2}-\omega_{m}\right)\left\{\alpha_{2}\left(\beta_{1}-\beta_{2}\right)+\left(\alpha_{1}-\alpha_{2}\right)\left(\beta_{2}-\omega\right)\right\}\right] / \mu_{3}\end{array}$ \\
\hline$\eta_{14}$ & $\begin{array}{l}{\left[\left(\beta_{2}-\omega_{m}\right)\left\{\alpha_{2}\left(\alpha_{2}-\alpha_{1}\right)-\left(\beta_{2}-\beta_{1}\right)\left(\beta_{2}-\omega\right)\right\}\right.} \\
\left.\quad+\alpha_{2}\left(\alpha_{2}\left(\beta_{1}-\beta_{2}\right)+\left(\alpha_{1}-\alpha_{2}\right)\left(\beta_{2}-\omega\right)\right\}\right] / \mu_{3}\end{array}$ \\
\hline$\eta_{15}$ & {$\left[\left(R_{s}-\alpha_{1} L_{s}\right)\left(\alpha_{2}-\alpha_{1}\right)+L_{s} \beta_{1}\left(\beta_{1}-\beta_{3}\right)\right] / \mu_{4}$} \\
\hline$\eta_{16}$ & {$\left[L_{s} \beta_{1}\left(\alpha_{2}-\alpha_{1}\right)-\left(\beta_{1}-\beta_{2}\right)\left(R_{5}-\alpha_{1} L_{s}\right)\right] / \mu_{4}$} \\
\hline$\eta_{17}$ & {$\left[\left(R_{s}-\alpha_{2} L_{s}\right)\left(\alpha_{1}-\alpha_{2}\right)+\beta_{2} L_{s}\left(\beta_{2}-\beta_{1}\right)\right] / \mu_{4}$} \\
\hline$\eta_{18}$ & {$\left[\beta_{2} L_{s}\left(\alpha_{1}-\alpha_{2}\right)-\left(\beta_{2}-\beta_{1}\right)\left(R_{s}-\alpha_{2} L_{s}\right)\right] / \mu_{\mathrm{a}}$} \\
\hline$\eta_{10}$ & {$\left[\alpha_{1}\left(\alpha_{1}-\alpha_{2}\right)+\left(\beta_{1}-\beta_{2}\right)\left(\beta_{1}-\omega_{m}\right)\right] / \mu_{4}$} \\
\hline$\eta_{20}$ & {$\left[\alpha_{1}\left(\beta_{1}-\beta_{2}\right)+\left(\beta_{2}-\omega_{m}\right)\left(\alpha_{2}-\alpha_{1}\right)\right] / \mu_{4}$} \\
\hline $7_{21}$ & {$\left[\alpha_{2}\left(\alpha_{2}-\alpha_{1}\right)+\left(\beta_{2}-\beta_{1}\right)\left(\beta_{2}-\omega_{m}\right)\right] / \mu_{4}$} \\
\hline$\eta_{22}$ & {$\left[\alpha_{2}\left(\beta_{2}-\beta_{1}\right) \div\left(\alpha_{3}-\alpha_{2}\right)\left(\beta_{2}-\omega_{m}\right)\right] / \mu_{4}$} \\
\hline
\end{tabular}

$\mu_{1}=\left\{\alpha_{1} \alpha_{2}-\left(\omega-\beta_{1}\right)\left(\omega-\beta_{2}\right)\right\}^{2}+\left\{\alpha_{1}\left(\omega-\beta_{2}\right)+\alpha_{2}\left(\omega-\beta_{1}\right)\right\}^{2}$

$\mu_{2}=\left\{\left(\alpha_{1}-\alpha_{2}\right) \alpha_{1}-\left(\beta_{1}-\omega\right)\left(\beta_{1}-\beta_{2}\right)\right\}^{2}+\left\{\left(\beta_{1}-\omega\right)\left(\alpha_{2}-\alpha_{1}\right)-\left(\beta_{1}-\beta_{2}\right) \alpha_{1}\right\}^{2}$ $\mu_{3}=\left\{\left(\alpha_{2}-\alpha_{1}\right) \alpha_{2}-\left(\beta_{2}-\omega\right)\left(\beta_{2}-\beta_{1}\right)\right\}^{2}+\left\{\left(\beta_{2}-\omega\right)\left(\alpha_{1}-\alpha_{2}\right)-\left(\beta_{2}-\beta_{1}\right) \alpha_{2}\right)^{2}$ $\mu_{t}=\left(\alpha_{1}-\alpha_{2}\right)^{2}+\left(\beta_{1}-\beta_{7}\right)^{2}$

ts が長いはざ $T_{\text {max }}$ は大きくなる傾向を示す。 本諭文で结解析に扔いて回路定数の非線形性を考虑 していないが，今徭，解析結果の精度向上拉よび中容 量以上の電動機について解析在行なうためには，磁気 飽和などを考慮する必要がある。從って，回路定数の 変化などの現象的な面について検討する予定である。

終りに，日頃御指導を賜わる本学，高木唱一教授な らびに東京電機大学電動力心用研究所長, 宮入生太教 授に感謝の意を表すると共に，東芝重電技術研究所の 秋山勇治氏心恳謝致します。また，寄験儿御協力頂い た窗藤和夫民 (パイオニア(株)), 本学大学院生赤沢一
付第 2 表 トルクの係数

app. Table 2, Coefficients of torque.

\begin{tabular}{|c|c|}
\hline 係数 & 係数の内容 \\
\hline$K_{1}$ & $\eta_{1} \cos (\omega t+\xi)-\eta_{2} \sin (\omega t+\xi)$ \\
\hline$K_{2}$ & $\eta_{1} \sin (\omega t+\xi)+\eta_{2} \cos (\omega t+\xi)$ \\
\hline$K_{3}$ & $\eta_{3} \cos \left(\beta_{1} t+\xi\right)-\eta_{4} \sin \left(\beta_{1} t+\xi\right)$ \\
\hline$K$ & $\eta_{3} \sin \left(\beta_{1} t+\xi\right)+\eta_{4} \cos \left(\beta_{1} t+\xi\right)$ \\
\hline$K_{5}$ & $\eta_{5} \cos \left(\beta_{2} t+\xi\right)-\eta_{6} \sin \left(\beta_{2} t+\xi\right)$ \\
\hline$K_{0}$ & $\eta_{5} \sin \left(\beta_{2} t+\xi\right)+\eta_{6} \cos \left(\beta_{2} t+\xi\right)$ \\
\hline$K_{?}$ & $\eta_{7} \cos \left(\beta_{1} t+\varphi-\pi / 2\right)-\eta_{8} \sin \left(\beta_{7} t+\varphi-\pi / 2\right)$ \\
\hline$K_{\mathrm{s}}$ & $\eta_{7} \sin \left(\beta_{1} t+\varphi-\pi / 2\right)+\eta_{8} \cos \left(\beta_{1} t+\varphi-\pi / 2\right)$ \\
\hline$K_{8}$ & $\eta_{7} \cos \left(\beta_{2} t+\varphi-\pi / 2\right)-\eta_{8} \sin \left(\beta_{2} t+\varphi-\pi / 2\right)$ \\
\hline$K_{\mathrm{to}}$ & $\eta_{1} \sin \left(\beta_{2} t+\varphi-\pi / 2\right)+\eta_{8} \cos \left(\beta_{2} t+\varphi-\pi / 2\right)$ \\
\hline$K_{\mathrm{nI}}$ & $\eta_{9} \cos (\omega t+\xi)-\eta_{10} \sin (\omega t+\xi)$ \\
\hline$K_{12}$ & $\eta_{9} \sin (\omega t+\xi)+\eta_{10} \cos (\omega t+\xi)$ \\
\hline$K_{13}$ & $\eta_{11} \cos \left(\beta_{1} t+\xi\right)-\eta_{12} \sin \left(\beta_{1} t+\xi\right)$ \\
\hline$K_{14}$ & $\eta_{11} \sin \left(\beta_{1} t+\xi\right)+\eta_{12} \cos \left(\beta_{1} t+\xi\right)$ \\
\hline$K_{15}$ & $\eta_{13} \cos \left(\beta_{2} t+\xi\right)-\eta_{14} \sin \left(\beta_{2} t+\xi\right)$ \\
\hline$K_{18}$ & $\eta_{13} \sin \left(\beta_{2} t+\xi\right)+\eta_{14} \cos \left(\beta_{2} t+\xi\right)$ \\
\hline$K_{17}$ & $\eta_{13} \cos \left(\beta_{1} t+\varphi-\pi / 2\right)-\eta_{16} \sin \left(\beta_{1} t+\varphi-\pi / 2\right)$ \\
\hline$K_{18}$ & $\eta_{15} \sin \left(\beta_{1} t+\varphi-\pi / 2\right)+\eta_{15} \cos \left(\beta_{1} t+\varphi-\pi / 2\right)$ \\
\hline$K_{19}$ & $\eta_{17} \cos \left(\beta_{2} t+\varphi-\pi / 2\right)-\eta_{18} \sin \left(\beta_{2} t+\varphi-\pi / 2\right)$ \\
\hline$K_{20}$ & $\eta_{17} \sin \left(\beta_{2} t+\varphi-\pi / 2\right)+\eta_{19} \cos \left(\beta_{2} t+\varphi-\pi / 2\right)$ \\
\hline$K_{21}$ & $\eta_{19} \cos \left(\beta_{1} t+\varphi-\pi / 2\right)-\eta_{20} \sin \left(\beta_{1} t+\varphi-\pi / 2\right)$ \\
\hline$K_{22}$ & $\eta_{19} \sin \left(\beta_{1} t+\varphi-\pi / 2\right)+\eta_{20} \cos \left(\beta_{1} t+\varphi-\pi / 2\right)$ \\
\hline$K_{23}$ & $\eta_{21} \cos \left(\beta_{z} t+\varphi-\pi / 2\right)-\eta_{22} \sin \left(\beta_{2} t+\varphi-\pi / 2\right)$ \\
\hline$K_{24}$ & $\eta_{21} \sin \left(\beta_{2} t+\varphi-\pi / 2\right)+\eta_{32} \cos \left(\beta_{3} t+\varphi-\pi / 2\right)$ \\
\hline
\end{tabular}

寿君に御礼申し上げる。なお，計算瀻 (FACOM 230/ 38）の使用にあたって，本学計算せンターの皆様に御 協力頂いたことを付記し，感謝します。

(昭和 54 年 6 月 20 日受付，同 54 年 11 月 9 日再受付)

\section{文献}

(1) C.F. Landy: "The prediction of transient torques pro duced in induction motors due to rapid reconnection of the supply ". SAIEE 63-7, p. 178 (1972-7)

(2) F.P. Flynn, R.D. Slater \& C. Eng: "Transient negat. ive torques in induction motors due to rapid reconnect. ion of the supply". Proc. Instn Elect. Engrs 116, 12, p. $2009(1969-12)$

(3) 猪特: 電気機棫理諭 p. 144（昭 52-1) コ口ナ社

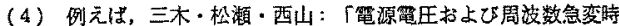

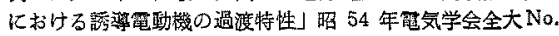
661

(5) W. V. Lyon: "Transient analysis of alternating-current machiney," (1954) John Wiley \& Sons

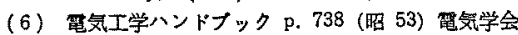

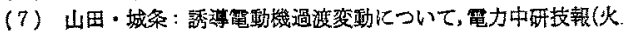
力 63003) p. 91 (昭 38-5)

(8) H.E. JORDAN: "Digital computer analysis of induction machines in dynamic systems." IEEE Trans. Pow. er Apparatus Syst. PAS-86. No. 6, p. 722 (1967) 